[Forthcoming, Journal of Monetary Economics]

\title{
Does Bank Lending Affect Output? Evidence From the U.S. States
}

\author{
John C. Driscoll \\ Federal Reserve Board ${ }^{1}$
}

\begin{abstract}
This paper uses a panel of state-level data to test whether changes in bank loan supply affect output. Since the U.S. states are small open economies with fixed exchange rates, state-specific shocks to money demand are automatically accommodated, leading to changes in lending if banks rely on deposits as a source of funding. Using these shocks as an instrumental variable, I find that shocks to money demand have large and statistically significant effects on the supply of bank loans, but loans have small, often negative and statistically insignificant effects on output.
\end{abstract}

JEL Classification Numbers:E32, E41, E51

Keywords: Bank Lending, U.S. States, Money Demand, Credit.

\footnotetext{
${ }^{1}$ Mail Stop 75,Federal Reserve Board, 20th and Constitution Avenue NW, Washington, DC 20551. Phone:(202) 452-2628, Fax: (202)452-2301, email:John_Driscoll@alum.mit.edu. I would like to thank John Leahy, N. Gregory Mankiw, Julio Rotemberg, the editor, two anonymous referees, seminar participants at Harvard, Brown, Michigan, Maryland, the Federal Reserve Bank of Boston and the Federal Reserve Board, as well as many others too numerous to mention for helpful remarks. All remaining errors are mine. I thank the National Science Foundation and Earle A. Chiles Foundation for financial support. The views expressed here are those of the author, and not necessarily those of the Federal Reserve Board or its staff.
} 
This paper examines whether changes in bank lending cause subsequent changes in income. There is a long tradition in the literature on monetary policy, beginning with Brunner and Meltzer (1963) and revived more recently by Bernanke (1983) and many others, that banks may play a special role in the propagation of economic fluctuations. This role arises from the conjecture that there may be many small firms which are bank-dependent, in the sense that they are unable to readily substitute other forms of finance for bank loans. Bank-dependence has three important consequences. First, the monetary transmission mechanism may work through the market for bank loans (the "lending channel" of monetary policy) as well as through the conventional interest-rate channel (the "money channel"). ${ }^{1}$ Second, bank failures may help cause recessions. ${ }^{2}$ Third, bank regulatory actions may be a source of monetary policy shocks potentially as important as changes in the Federal Funds rate. ${ }^{3}$

There are several difficulties in testing for the presence of the lending channel. The first is the reverse-causality or endogeneity problem: one must determine that correlations between output and money are due to output responding to money and not money demand to expectations of future output. Solving this problem, which is usually done by instrumenting for shocks to the money supply, determines the total effect of monetary innovations on output. The second difficulty is determining how much of this effect is attributable to the lending channel and how much is attributable to the money channel, done through another identifying assumption or a parametric restriction.

Answering the related question "Do bank loans have effects on output" involves similar difficulties. Since the demand for loans presumably depends on the level of output, there is simultaneous equations bias in running a regression of output on the quantity of loans. There is also a reverse causality problem: loans may be endogenously rising in response to expected future increases in output.

Because of the difficulty in finding even one good instrument for monetary innovations, and the additional trouble in finding an exogenous shock to the loans market, empirical tests of the lending channel have arguably not yielded

\footnotetext{
${ }^{1}$ See Kashyap and Stein (1994) and the Fall 1995 Journal of Economic Perspectives for recent surveys.

${ }^{2}$ See Bernanke (1983) for a discussion of the role of bank failures in the Great Depression and Bernanke and Lown (1991) and Peek and Rosengren (1995a,b) for a discussion of the "credit/capital crunch" in the 1990-1991 recession.

${ }^{3}$ Peek and Rosengren (1995a).
} 
consistent results for or against its economic importance.

In this paper, I exploit the fact that the U.S. states may be viewed as a group of small open economies under fixed exchange rates to circumvent these problems. I extend the aggregate-demand model of Bernanke and Blinder (1988) to this setting; the resulting model implies that state-specific shocks to money demand should lead to state-specific changes in the supply of loans, and therefore changes in output, if there is a lending channel.

A simple story illustrates the model. Suppose there is a money demand shock in Massachusetts, so that for a given level of output and the interest rate, people wish to hold more money. The aggregate interest rate is exogenous from the perspective of Massachusetts. Given this, and the fact that the 'exchange rate' between Massachusetts' currency and other states' currencies must remain constant, there must be accommodation: real balances will rise in Massachusetts and decrease slightly everywhere else. If only the traditional liquidity preference channel exists, the story ends here; output in Massachusetts is unaffected. Yet if there is a lending channel, the increase in real deposits will produce an increase in bank loans. Since at least some firms do not regard loans as a perfect substitute for other forms of finance, they will increase investment, and Massachusetts income will increase. ${ }^{4}$

Thus state-specific money demand shocks will be a good instrument for shocks to loan supply in regression of output on loans. This approach has two additional advantages over other approaches to testing the lending channel. First, the Federal Reserve cannot smooth state-specific shocks, both from the fixed-exchange rate structure and from the lack of state-level central banks. Hence the money channel is not operational for state-specific changes in output. Second, by looking at both the first and second-stage regressions, we can test two key assumptions needed by the lending view. The first stage regressions of loans on the money demand shocks will test whether the quantity of deposits restricts bank lending. The second stage regression tests whether changes in the supply of bank loans have effects on output. Previous studies either test these two hypotheses jointly, or test only one of them.

Using a panel of annual data on the U.S. states, I find that shocks to money demand have a large and statistically significant effect on loans. Upon instrumentation, however, shocks to the supply of loans have a generally

\footnotetext{
${ }^{4}$ Output will decrease in all other states, but by an amount which is small relative to the magnitude of the shock. I am also not claiming that shocks to money demand are an important part of aggregate or even Massachusetts fluctuations; rather, they are simply a useful device for testing for the existence of a lending channel.
} 
small, often negative, and statistically insignificant effect on state personal income. Both results are robust to the choice of time period and crosssectional unit.

Thus the first requirement of the lending channel, that banks are not able to readily substitute for deposits, seems to be true. The results do not support the second idea, that firms are bank-dependent

This paper consists of five sections after this introduction. Section 1 presents the model and discuss identification, and section 2 describes the data and empirical specification. Section 3 presents the results. Section 4 discusses robustness issues and relates the results to the literature. Section 5 concludes.

\section{Theory and Identification}

The following is an extension of the Bernanke and Blinder (1988) aggregate demand model of the lending channel to the case of a group of small open economies under fixed exchange rates. As the model is meant to illustrate identification problem and its proposed solution, it is kept deliberately simple.

Suppose there are $N$ states indexed by $i \in(1, \ldots, N)$. These states share a common monetary authority. Individuals can hold bank deposits, $m$ or bonds; bonds bear interest at rate $r$, the same in all communities. ${ }^{5}$

Bank deposits have an interest rate $r^{d}$, which may vary across states. The monetary authority can change the aggregate quantity of money, but is unable to target the exact quantity of money in a particular community.

Hence the condition that money supply equal money demand may be written in the following typical fashion:

$$
m_{i t}-p_{i t}=\gamma y_{i t}-\delta\left(r_{t}-r_{i t}^{d}\right)+\epsilon_{i t}
$$

Here, $\epsilon_{i t}$ represents state-specific shocks to money demand. These may arise, for example, from changes in the characteristics in bank deposits, changes in the relative demand for currency and bank deposits, or from differences across states in the introduction of ATMs or of credit cards.

\footnotetext{
${ }^{5}$ These assumptions are equivalent to assuming that each community is a small open economy with fixed exchange rates and a limited kind of perfect capital mobility.
} 
Income is equal to expenditure, which as usual is divided into consumption, investment, government spending and net exports. Assume that government spending is exogenous, and net exports a function of the constant real exchange rate and possibly output. Investment will be a function of the interest rate on bonds, $r$ and the interest rate on loans, $\rho$. The latter is allowed to differ across states; this assumption is key, and I will argue for its plausibility in section 4.1 below. Firms do not regard loans and bonds as perfect substitutes. Suppose that we may write consumption as a function of output and the two interest rates. Then, solving out for income, we may write this part of aggregate demand as:

$$
y_{i t}=-\theta r_{t}-\alpha \rho_{i t}+z_{i t},
$$

where $z_{i t}$ represents other unmodeled disturbances to aggregate demand (e.g. from fiscal policy or changes in tastes).

Loans are supplied by banks. Banks have deposits as liabilities, and can either make loans or hold bonds as assets. Assume that banks do not regard loans and bonds as perfect substitutes in their portfolios, and are also not able to readily substitute other forms of finance for deposits. Then the supply of loans ${ }^{6}$ may be written as follows:

$$
l_{i t}^{s}=-\lambda r_{t}+\mu \rho_{i t}+\beta\left(m_{i t}-p_{i t}\right)+w_{i t},
$$

where $w_{i t}$ represent unmodeled disturbances which might affect loan supply (e.g. changes in banking regulations). ${ }^{7}$

Firms demand loans. They have a choice in finance between loans and bonds. We may write loan demand as:

$$
l_{i t}^{d}=\tau r_{t}-\chi \rho_{i t}+\omega y_{i t}+v_{i t},
$$

where $v_{i t}$ represents shocks to the demand for loans. For identification, I will need to assume that $\operatorname{corr}\left(\epsilon_{i t}, z_{i t}\right)=\operatorname{corr}\left(\epsilon_{i t}, v_{i t}\right)=0$. I defer discussion of the consequences of violating these and the other identification assumptions until section 4.1.

\footnotetext{
${ }^{6}$ One could also add a term in the interest rate on deposits without affecting subsequent results, although it is not clear why the deposit rate would necessarily affect the choice of assets.

${ }^{7}$ A number of authors, including Peek and Rosengren (1995a) and Ostergaard (2000) have used specific measures of such changes to determine how loan supply responds to regulatory changes.
} 
Jointly, equations (1) through (4) determine aggregate demand for this economy. Several aspects of these equations deserve comment. The key assumptions of the lending channel are those that firms do not regard bank loans and bonds as perfect substitute, and that banks do not regard loans and bonds as perfect substitutes. The former is usually justified by assuming that there are some (small) firms which do not have access to equity or bond markets. Here, it is assumed that firms are affected by bank lending within the same state. Although this suggests that the model is more about a regional lending channel than an actual lending channel, it does not seem unreasonable to assume that a large number of the firms which are bank-dependent are also state-bank-dependent. The division by state is then simply a convenient way of getting at these small firms. Section 4.1 will present some evidence bearing on this assumption.

The model also assumes that loans in state $i$ may be affected by the quantity of deposits in state $i$. This may not be true if either banks are willing to lend out of state or can use deposits in out-of-state branches to fund withinstate lending. Both are unlikely, for two reasons. First, Federal regulation until quite recently has severely restricted the out-of state lending behavior of banks. Interstate branching has been confined to consortia of states with reciprocal banking agreements. ${ }^{8}$ This suggests that the appropriate unit to consider may not be the state, but may be the geographic region; this matter will be reconsidered in the empirical part of the paper. Second, banks may be unwilling to lend to out-of-state banks for the same reasons that they are unwilling to lend to out-of-state firms: lack of information about the quality of the banks. This assumption is discussed further in section 4.1.

Equations (1) through (4) cannot directly be used to determine that monetary shocks will affect output through loans. Even if one were able to identify innovations in the supply of real balances, one would still have to separate the effects occurring through $r$ from those occurring through $\rho$.

These problems may be eliminated by noting that the liquidity preference channel works on the aggregate level. Formally, we may see this by demeaning each variable. Let $\tilde{x}_{i t}$ denote $x_{i t}-\frac{1}{N} \sum_{i=1}^{N} x_{i t}$, i.e. the deviation of $x$ from its cross-sectional average. Then we may write the demeaned versions of equations (1) through (4) as:

$$
\tilde{m}_{i t}-\tilde{p}_{i t}=\gamma \tilde{y}_{i t}+\delta \tilde{r}_{i t}+\epsilon_{i t}
$$

\footnotetext{
${ }^{8}$ See Savage(1987) for an extended discussion of this issue.
} 


$$
\begin{gathered}
\tilde{y}_{i t}=-\alpha \tilde{\rho}_{i t}+z_{i t} \\
\tilde{l}_{i t}^{s}=\mu \tilde{\rho}_{i t}+\beta\left(\tilde{m}_{i t}-\tilde{p}_{i t}\right)+w_{i t} \\
\tilde{l}_{i t}^{d}=-\chi \tilde{\rho}_{i t}+\omega \tilde{y}_{i t}+v_{i t}
\end{gathered}
$$

In equations (5) and (8), the liquidity preference channel has been eliminated; the effects of monetary policy through the interest rate on bonds are no longer present. This essentially arises from the fact that the monetary authority cannot cause the aggregate interest rate to differ across states. It is still possible, however, that money demand will respond endogenously to expected future changes in output. Thus this approach does not solve the problem of endogenous money.

Rewrite this in a form that demonstrates the dependence of output on loans by solving for $\rho_{i t}$ in equation (8) and substituting into equations (6) and (7), and substitute equation (5) into equation (7). The resulting two equations are:

$$
\begin{gathered}
\tilde{y}_{i t}=\frac{\alpha}{\chi+\omega \alpha} \tilde{l}_{i t}-\frac{\alpha}{\chi+\omega \alpha} v_{i t}+\frac{\chi}{\chi+\omega \alpha} z_{i t} \\
\tilde{l}_{i t}=\frac{\chi \beta}{\chi+\mu} \epsilon_{i t}+\frac{\chi \beta \gamma+\omega \mu}{\chi+\mu} \tilde{y}_{i t}-\frac{\mu}{\chi+\mu} v_{i t}+\frac{\chi}{\chi+\mu} w_{i t}+\frac{\beta \delta \chi}{\chi+\mu} \tilde{r}^{d}{ }_{i t}
\end{gathered}
$$

In principle, to examine the effects of bank loans on output, one would like to estimate equation (9) and test the hypothesis that $\frac{\alpha}{\chi+\omega \alpha}$, the coefficient on $\tilde{l}_{i t}$, is zero. Note that this is equivalent to testing the hypothesis that the coefficient on $\rho_{i t}$ in equation (2) is zero. However, the presence of (10) indicates that OLS estimates of $\frac{\alpha}{\chi+\omega \alpha}$ will be biased; hence I must instrument. An obvious choice for the instrument is $\epsilon_{i t}$; from (10), it is correlated with $\tilde{l}_{i t}$, but it is uncorrelated with any of the disturbance terms in (9) (and in particular with shocks to the demand for loans).

A major advantage of using $\epsilon_{i t}$ as an instrument is that it will also allow for tests of the question "Do changes in deposits affect the quantity of loans?" In the first-stage of the two-stage least squares/IV procedure, loans will be regressed on the money demand shocks. If the coefficients on the shocks are statistically insignificant, then it is not only the case that the money demand shocks are invalid instruments, but it is also true that loans will not respond to shocks to money demand or money supply. That loans respond to monetary shocks is a necessary condition for the lending channel of the monetary transmission mechanism to operate. 
Previous researchers have also attempted to estimate (9) via instrumental variables. However, they have either chosen to instrument with other shocks to the market for loans here, represented by $w_{i t}$, that are unrelated to monetary innovations, or have chosen shocks to the money supply. The former approach cannot test all the conditions necessary for the operation of a monetary transmission mechanism through the market for bank loans. The latter has the difficulties that it is difficult to find indisputably good instruments for shocks to money supply and difficult to separate effects of money working through the lending channel rather than through other means.

A more intuitive way of understanding this technique is to view the communities as small open economies under fixed exchange rates. The latter comes in from the common currency and the common aggregate interest rate. The monetary authority can still perform monetary policy on the economy as a whole, but not on individual communities; since dealing with the aggregate economy has the usual problems outlined above, eliminate it by demeaning all variables. In this framework, community-specific shocks to money demand are automatically accommodated; failure to do so would mean a change in the aggregate interest rate (which is given from the perspective of each state) or a change in the 'exchange rate' (an impossibility). In response to such shocks, the quantity of loans made by banks in a specific community may change, but otherwise the story ends here if there is no lending channel. If in fact some firms are dependent on loans made by banks in the same community, so that there is a lending channel, output will change with the quantity of loans. Hence the existence of a lending channel implies that money demand shocks have real effects under a fixed-exchange rate regime.

The above model was a model of aggregate demand in which shocks do not have persistence. Completing the model would involve adding aggregate supply. One can generate persistence in the aggregate demand shocks through contracting models or other models of aggregate supply which imply real effects of nominal disturbances. It should also be noted that the phenomenon being tested, that shocks to money demand lead to changes in lending and then to changes in income, can also be an entirely real channel. Thus the empirical tests will be consistent with other models in which prices are perfectly flexible, but nominal and real shocks are transmitted through the banking sector, as in Rotemberg (1984) or Fuerst (1992). 


\section{$2 \quad$ Data and Empirical Strategy}

Annual data on total deposits, total loans, and commercial and industrial loans in commercial and mutual savings banks are available for the US states for 1934 to 1998 from the FDIC. ${ }^{9}$ Data on total deposits and total loans in savings in loans is available from FSLIC, the Federal Home Loan Bank Board and the Office of Thrift Supervision and the FDIC from 1948 to $1998 .^{10}$

The data on loans represent the book value of all commercial and industrial loans and all loans made by banks located within a state. ${ }^{11}$

Following the practice of the literature on the lending view, I use the commercial and industrial (C\&I) loans figures on the grounds that they are the type of loans likely to be most relevant to businesses. Only commercial and mutual savings banks make C\&I loans, as savings and loans focus almost exclusively on mortgage loans.

Since classification schemes of loans may change over time, and loans not classified as C\&I loans may nonetheless have been used for business investment, I also use all loans made by banks within a state. I compute this measure both with and without loans made by S\&Ls (thrifts), since S\&Ls are not subject to the same restrictive rules on branching and thus may not satisfy the assumptions of the model as well.

The relevant measure of money for this model is those components of money which affect the ability of banks to make loans. This consists of all bank deposits, or M3 less currency and travelers' checks. For regressions in which I use only C\&I loans, and thus only data from commercial and mutual savings banks, I use only monetary data from these banks. Interest rates on these deposits were obtained by dividing the interest paid out on deposits by the quantity of deposits. These rates vary only by an small amount (frequently by fewer than twenty basis points) across states for much of this period, since most rates were at their Regulation-Q maxima. ${ }^{12}$ As some

\footnotetext{
${ }^{9}$ In Assets and Liabilities of Operating and Insured Banks from 1934 to 1978, in Bank Operating Statistics from 1979 to 1983 and in Historical Statistics on Banking: A Statistical History of the U.S. Banking Industry from 1984 to 1998.

${ }^{10}$ In Combined Financial Statements of FSLIC-Insured SELs from 1948 to 1967, from Federal Home Loan Bank Board Journal from 1968 to 1984, and from the FDIC thereafter.

${ }^{11}$ Despite being book rather than market, the figures plummet in value for many states in the 1980s, even prior to the 'credit crunch' of 1990-1992. In Louisiana, for example, the real value of loans dropped by nearly half in a seven-year period.

${ }^{12}$ The quantity measures for money are comparable to those used in Mulligan and Salai-Martin (1993). They mistakenly characterize it as M2 less currency, however, since they
} 
of the components of M3 may not offer any monetary services, which may lead equation 1 to be misspecified, I also use a measure of money consisting of demand deposits and savings deposits (i.e. M2 less currency and time deposits). This data is only available for commercial banks from 1975 to 1998. This issue is discussed further in section 4.1.

Annual data on state personal income from 1929 to 1998 is available from the Bureau of Economic Analysis. However, the degree of interpolation of this data prior to 1965 is substantial, ${ }^{13}$ and thus I only use data from 1965 to 1998.

Since price-level series do not exist for all states, I use the GDP deflator to deflate nominal values for all states. Since all data are demeaned from cross-sectional averages, in practice the deflator drops out.

As suggested in the previous section, it is possible that states are not the appropriate level to consider, since even small firms may be able to borrow out of state. I deal with this problem in two ways. First, I eliminate states which contain cities with money center banks which are likely to do substantial amounts of out-of-state lending: New York, California and Illinois. Thus, all state-level regressions consist of observations on 47 states and the District of Columbia.

Second, I aggregate the states up into regions. While it would be natural to aggregate by Federal Reserve District, this is not possible since districts cut across state lines. As a convenient regional-level aggregator(which in fact is very similar to the bank-loan agreement areas mentioned above), I use the nine U.S. Census regions. ${ }^{14}$

To obtain a level of state-specific money demand shocks, I estimate equation 5 for each state. ${ }^{15}$ To provide some idea of how these estimates compare to conventional money demand estimates, below I present versions for M2 and M3 in which I have forced all coefficients to be the same across states.

are apparently unaware of deposits held at savings and loans.

${ }^{13}$ As discussed in Bureau of Economic Analysis (1989).

${ }^{14}$ New England (CT,MA,ME,NH,RI,VT), Middle Atlantic (NJ,NY,PA), East North Central (IL,IN,MI,OH,WI), West North Central (IA,KS,MN,MO,NB,ND,SD), South Atlantic (DE,DC,FL,GA,MD,NC,SC,VA,WV), East South Central (AL,MS,KY,TN), West South Central (AR,LA,OK,TX), Mountain (AZ,CO,ID,MT,NV,NM,UT,WY) and Pacific (AK,CA,HI,OR,WA).

${ }^{15}$ While under the null hypothesis of no lending channel, this can be estimated consistently, under the alternative of a lending channel, estimates will be biased because the error term is correlated with output. In practice, I cannot reject the hypothesis that all states have the same money demand function. 
M2 less currency:

$$
\tilde{m}_{i t}-\tilde{p}_{i t}=1.26 \quad \tilde{y}_{i t}-.004 \tilde{r}_{i t}
$$

M3 less currency:

$$
\tilde{m}_{i t}-\tilde{p}_{i t}=1.58 \tilde{y}_{i t}-.075 \tilde{r}^{d}{ }_{i t}
$$

In both cases, income elasticities are slightly larger than those usually obtained for simple linear money demand specifications, although they are in lines with the results of Mulligan and Sala-i-Martin (1992) using similar data. The results are more precise and are closer to conventional values for the state-by-state estimates.

I exploit the cross-section and time-series nature of the data set to estimate the model as a pooled panel regression. Since all data are demeaned from cross-sectional averages, there is no need to include time dummies. I also first difference the data, since testing for unit roots revealed that some of the series could not be rejected as being nonstationary. ${ }^{16}$ This has the additional advantage of eliminating the need to control for fixed effects. All regressions include two lags, as suggested by the SBIC.

Since there may still be contemporaneous and lagged correlation across units, even despite the demeaning and first-differencing, I therefore correct the standard errors for spatial correlation, autocorrelation and heteroskedasticity using Driscoll and Kraay's (1998) extension of Newey and West's nonparametric variance-covariance estimator.

\section{Results and Discussion}

\subsection{Results}

Table 1 verifies that for this new state- and regional-level data set, the same relationship holds between output and lending as is the case in national-level data sets. The positive correlation between output and lending is statistically

\footnotetext{
${ }^{16}$ It is difficult, however, to reconcile this result with the convergence hypothesis, although it seems similar to results obtained in Blanchard and Katz (1992) for the labor market. It should also be noted that techniques to estimate a fixed-effects version of the model in levels, such as that of Holtz-Eakin, Newey and Rosen (1988), rely on large-N asymptotics, which are inappropriate when $\mathrm{N}$ and $\mathrm{T}$ are approximately the same size.
} 
stronger for C\&I loans. The third-to-last column reports the F-statistic for excluding the loans variables; they cannot be excluded at the one percent level for eight of the ten specifications.

Economically, the effects for both types of loans are small. For C\&I loans, for example, a growth rate of one percentage point above the national average for loans made by banks in state $i$ is associated with a personal income growth rate which is .017 percentage points above the national average. Since the growth rate of loans frequently varies by more than 10 percentage points above and below the average, and average growth of real per capita income is between 2 and three percent per year over this sample, the effects are not negligible.

This is a reduced-form regression, and we cannot conclude from it that the relationship is due to loan supply or that the effects of loan supply on output are small. As discussed above, I use shocks to state-level money demand as an instrument for loan supply. Table 2 presents the first stage regression of loans on output and the money demand shocks.

In all of the specifications, the money demand shocks have statistically and economically significant effects on the quantity of loans. The effects are stronger at the state level and are strongest contemporaneously. For C\&I loans, if shocks to money demand grow at a rate of one percentage point above the cross-sectional average rate, loans will grow by 1.11 percentage points more in the first year. The effects are thus likely to be large even if money demand shocks are themselves small. As expected, the effects of the M2-based money demand shocks are smaller; they also come in with a lag. These results suggest that the level of bank deposits may in fact be an important determinant in loan supply, and that money demand shocks are appropriate instruments for the regression of output on loans.

Table 3 reports the results of rerunning the regression of Table 1 but using money demand shocks as instruments (where the measure of money is total deposits less currency). The coefficients on loans are slightly larger in absolute value than those reported in Table 1, but none is statistically significant, and more importantly many have the wrong sign (i.e. they suggest that increases in the growth rate of loan supply lead to contemporaneous decreases in income growth).

Is it possible that these results are due to weak instruments? Staiger and Stock (1997) have shown that when first-stage $F$-statistics are small, secondstage estimates will be biased towards the (also biased) OLS estimate and have non-standard confidence intervals. For a single regressor, the amount 
of the bias is inversely proportional to the first-stage $F$.

In six of the ten specifications, first-stage $F$ s are greater than ten, suggesting that this is not likely to be problematic; a bias less than $\frac{1}{10}=10 \%$ is not enough to overturn the wrong sign or make the results large. For the other four specifications, the second-stage results should be interpreted with caution, although those results are similar to the first six and do not have very large standard errors.

\section{Identification and Robustness}

\subsection{Identification}

This subsection discusses the consequences of violations of the identification assumptions.

First, it is possible that the money demand equations (1) and (5) are misspecified because the measures of money used may contain assets which do not provide transactions services. For those assets, intertemporal assetpricing equations would be more accurate, implying that the measured $\epsilon_{i t}$ may be correlated with future income and is thus invalid as an instrument. ${ }^{17}$

As is discussed in the literature on monetary aggregation ${ }^{18}$, assets may provide different degrees of monetary services. There is a positive relationship between the degree of monetary services and the difference between the interest rate on a benchmark non-monetary asset (usually taken to be the 3 month T-bill or prime-grade commercial paper rate) and the interest rate on the asset in question; hence currency, with a zero interest rate, provides a higher degree of monetary services than NOW accounts. According to this approach, for all assets with an interest rate less than the benchmark rate, it is possible to write down an intratemporal optimality condition which can be linearized to give a standard money demand equation of the form (1). An appropriate definition of money would consist of assets which satisfy this property.

\footnotetext{
${ }^{17}$ Although note that since aggregates such as M2 and M3 contain both assets which do provide transactions services and assets which may not, it is quite likely that variations in expected future income will cause reallocation among different components of M2 and M3, but no change in the level of M2 and M3.

${ }^{18}$ See Barnett et. al. (1992) for a survey, and Rotemberg, Driscoll and Poterba (1995)for an application.
} 
By this criterion, all types of demand deposits, and savings deposits, but not time deposits, provide monetary services. Hence the M2-like measure is consistent with the money demand equation. The M3-like measure (i.e. total deposits) contains a substantial number of assets which do not provide monetary services, and hence for those regressions the equation is likely to be misspecified.

However, the consequences of misspecification in this manner should result in biasing the second-stage results upwards. If the measured $\epsilon_{i t}$ are in fact improperly positively correlated with future income, the instrumented effects of output on loans should be spuriously higher. Since the results in table 3 are small or negative, if positive bias is present then the true effects of variations in loan supply on output should be even smaller or more negative, which is still inconsistent with the lending view.

Second, it is possible that the orthogonality assumptions placed on the error terms may not be satisfied. Considering equations (9) and (10), problems will arise if the money demand shock $\epsilon_{i t}$ is correlated with the IS shock $z_{i t}$ or the loan demand shock $v_{i t}$. It is not obvious to me why the first two should be correlated. However, it is possible that the loan demand shock and money demand shock can be correlated, either because banks require firms to hold deposits as a precondition for lending, or because money demand directly affects loan demand. In this case, because output is negatively correlated by the money demand shock, the bias in the estimated effect of loan supply on output will be negative, which is problematic for the interpretation of the results given above.

Letting $\zeta=\frac{\alpha}{\chi+\omega \alpha}$, the coefficient on loans in equation (9), one can show that the estimated $\hat{\zeta}=\zeta\left(1-\frac{1}{\eta} \operatorname{corr}(v, e) \frac{\sigma_{v}}{\sigma_{\epsilon}}\right)$, where $\eta=\frac{\chi \beta}{\chi+\mu}$, the effect of money demand shocks on loans, and $\sigma_{v}$ and $\sigma_{\epsilon}$ are the standard errors of the loan demand shocks and money demand shocks, respectively. Hence the bias will be large if $v$ has a large standard error relative to epsilon, or if $\eta$ is small; intuitively, if money demand shocks have little effects on loans, but are correlated with shocks to output, the estimated response of output to loans will really reflect the shocks to output. In practice, $v$ cannot be observed separately from the IS shock $z$, but if we assume the two are orthogonal, the standard error of the estimate for the first-stage IV regression provides an upper bound on $\sigma_{v}$. Using this estimate, the observed $\sigma_{\epsilon}$ and the estimated value of $\eta$ of about 1, we get an upper bound on the downward bias of about one third $\left(\frac{.069}{200}\right)$. This is not enough to qualitatively change the results. 
Third, the second stage regressions test the joint hypotheses that banks primarily lend locally and that there are local-bank-dependent firms. If firms are bank-dependent but can borrow from banks nationally, there may still be a lending channel, but not a regional lending channel.

There is a large and somewhat inconclusive literature in economic history, banking and antitrust on whether deposit and lending markets are geographically segmented ${ }^{19}$. Bodenhorn (1995) and Eichengreen (1994) have used risk-adjusted interest rate measures to argue that all lending markets and mortgage markets in particular have become more integrated over time. Davis(1995) has countered that there are remaining differentials not explained by risk which are systematically higher in some regions. Until recently, there were significant restrictions on out-of-state banking (surveyed by Savage (1987)). Berger,Kashyap and Scalise (1995) report that even after significant deregulation, in 1994 over seventy percent of bank assets were still controlled by within-state entities. They and Berger and Hannan (1999) find that changes in regional regulation have had little effect on bank profits, suggesting that local monopoly power remains. Cyrnak and Hannan (1999) find that entry of out-of-state banks has little effect on bank lending rates.

Figure 1 provides some additional evidence on the issue of integration for this sample by plotting the difference between regional interest rates (that is, rates on loans made by banks in each region) and the national average. These loan rates are obtained by dividing income on total loans by the quantity of loans. Since loan maturities may exceed one year, and since defaults may reduce loan income, these will not be an accurate reflection of the true interest rates on new loans at a yearly frequency. Nonetheless, they may be a good guide to broad differences in loan rates over time.

By looking at the outer envelope of the series, one can see that regions frequently differ from the average by over fifty basis points, and from each other by up to two hundred basis points. Some, but not all, regions, are persistently above or below the average.

One might argue that these differences primarily reflect differences in riskiness across regions. But this argument does not apply to this way of measuring interest rates. To see this, note that there are two ways of measuring interest rates for total loans on the regional level:

1. Compute a weighted average of rates loans made to firms in a particular region

\footnotetext{
${ }^{19}$ See Buch (2000) for a recent survey.
} 
2. Compute a weighted average of rates on loans made by banks in a particular region

These two measures need not coincide. Suppose firms in one region have riskier projects on average. Then, those firms should face higher rates, and this should be reflected in the first measurement method. But by the CAPM or other asset-pricing theories, banks in that region should attempt to diversify their lending portfolios by lending to firms in other, less risky regions. Hence the interest rate on the banks' total loan portfolio should reflect aggregate risk, but not region-specific risk. The only way they could regional risk if in fact banks are primarily or exclusively lending locally, in which case markets are segmented. Hence using the second measurement method, as this paper does, differences in rates due to regional risk differences are evidence for segmentation, not against it.

\subsection{Robustness}

In spite of the exclusion of three states with money-center banks and the aggregation into regions, it could still be the case that the results are contaminated by the presence of large states or other states which contained financial centers. Table 4 presents the results of reestimating tables 1 through 3 using only the 17 smallest states (by SPI) and by excluding states which contain a Federal Reserve Bank. The OLS regressions and both stages of the IV regressions are similar to those reported in Tables 1 to 3 ; in fact, the second stage results are somewhat smaller.

Table 4 also reports the results of extending the sample back to 1938. The OLS regression shows a significantly stronger relationship between output and loans. The first-stage IV regression is slightly smaller economically but highly statistically significant. The second-stage regression are statistically significant, but comes in with the wrong sign.

To correct for the lack of regional price data, I also try to reestimate the results for the period over which city-level CPI deflators are available (not reported). The point estimates are qualitatively similar, although some of the first-stage regressions are now statistically insignificant, due presumably to the shorter sample.

I also try two further measures for the money demand shock. For the first measure, I use a 'natural experiment' which may have resulted in a statespecific shock to money demand. NOW accounts were introduced at separate 
times in a number of Northeastern $\operatorname{states}^{20}$ before they were authorized nationwide in 1980. To the extent that introduction of these accounts caused people to shift assets from non-money to money, rather than just reallocating their holdings of monetary assets, this would be a measure of a state-level money demand shock. I create a dummy variable for these events, which is one for the year in which they are introduced and zero in all other years. The NOW account shocks are not significant in the first-stage regression for any of the specifications, and do not seem to be well-correlated with the other money demand shocks.

For the second measure, I impose the same money demand equation for each state. The results are qualitatively similar to the results obtained by estimating state-by-state, which is not surprising since I usually cannot reject that the same money demand function is valid for each state, as noted above. $^{21}$

Finally, Gertler and Gilchrist(1993) have argued that loan demand may in fact be countercyclical. This implies that the quantity of loans may not be a good indicator of the strength of the lending channel. To account for this possibility, I redo the results of Tables 1 through 3 using the average interest rate on loans as the lending variable. As noted above, this measure may not in fact well reflect year to year variation in lending rates. Doing so again yields qualitatively similar results: there is a significant uninstrumented relationship between state-level income and the lending rates (now negative: a 100 basis point change in the lending rate is associated with a decline in state-level income growth of .8 percent), a strong relationship between the money demand shocks and lending rates, and a small but imprecisely estimated effect of loan supply on GDP.

\subsection{Relation to the Literature}

The results of this paper complement previous findings of a link between monetary policy or regulatory actions and the equilibrium quantity of bank

\footnotetext{
${ }^{20}$ In 1973 in Massachusetts and New Hampshire, 1976 in Connecticut, Vermont, Maine and Rhode Island, 1979 in New York and 1980 in New Jersey.

${ }^{21} \mathrm{I}$ also tried using demand deposits as a measure of money. The second-stage results do not differ in any important qualitative way from the results obtained above. The firststage results, while still statistically significant, had small $F$ statistics and were not very economically significant. This is not surprising, as one would not expect demand deposits alone to be a significant limiting factor as a supply of funds for bank lending.
} 
loans. Peek and Rosengren (1995a) have shown that bank lending declines after formal regulatory actions are imposed on banks. Kashyap, Stein and Wilcox (1993) have found that the commercial-paper/loans 'mix' changes after innovations in monetary policy for a sample of small manufacturing firms. Kashyap and Stein (2000), using a very large panel data set, find that small, less liquid banks have a larger lending reaction than larger, better capitalized ones. Morgan (1993) finds that bank loans not under commitment decline with monetary policy innovations. Bernanke and Lown (1991) find, using a shorter but higher-frequency panel of state-level data than this paper, that the level of equity capital has some effect on the quantity of bank loans, although there is little relationship between banks' capital to asset ratios and state employment growth; this second finding is consistent with what is found here. However, Bernanke and Lown also find little evidence that the contraction in credit in 1990-91 is due to a shortage of funds, contrary to the results of this paper. This aspect of the lending channel has been particularly controversial, as Romer and Romer (1990) and others have claimed that banks can readily substitute other forms of finance for loans.

Most of the literature has focused on the second question addressed in this paper, whether bank loan supply has real effects.

At the microeconomic level, there appears to be substantial evidence that the impact of a change in bank lending is most severe on small firms (Gertler and Gilchrist (1994)). Oliner and Rudebusch (1996) argue that this is a consequence of a "broad credit channel", and not a bank lending channel. In a series of papers, Peek and Rosengren (1995b, 2000) and Peek, Rosengren and Tootell (2000) use regulatory actions and shocks to the parent banks of foreign-owned subsidiaries as measures of loan supply shocks. They find real effects on the behavior of local construction firms.

Evidence of a lending channel at the aggregate level is more mixed (see the survey by Kashyap and Stein (1994) and the subsequent comment by Eichenbaum (1994) for a summary of this debate).

Using state-level data, Hall (1993) finds loans to be Granger-causally prior in a bivariate system with output, and Samolyk (1994) finds that measures of local-credit tightness have greater predictive power for output in states with lower past quality of bank loans.

One might ask how it is possible that there can be variations in the supply of loans without corresponding variations in output. One possibility is that firms are not in fact bank-dependent, and are able to substitute other forms of finance, such as bond or equity financing for firms with ready access to 
such markets, or trade credit or other kinds of borrowing from other firms in the case of firms which do not have such access. These possibilities underly the work by Gertler and Gilchrist (1994), and Oliner and Rudebusch (1996). The latter provide evidence for a "broad credit channel," in which collateral effects change the terms of all forms of borrowing after a monetary policy shock.

A second possibility is that firms are able to buffer themselves from shortterm shocks in the lending market through inventories or changes in capacity utilization. This possibility is considered by Wang (2001), who calibrates a model with capacity utilization and finds that long-run averages of output and the capital stock are not affected by financial disturbances.

\section{Conclusion}

The existence of a lending channel in the Bernanke and Blinder (1988) sense depends on the existence of a connection between monetary shocks and bank loans and a connection between bank loans and real output. I find that statespecific money demand shocks have economically and statistically significant effects on the quantity of loans made by banks in that state. After using those shocks as instruments, I find slight evidence against the contention that shocks to the supply of bank loans raise output. These results are robust to changes in sample size and choice of cross-sectional unit.

The first result adds more evidence to the large body of literature suggesting that the Federal Reserve can affect banks' lending decisions. Even if the second part lending channel were not true (which is consistent with the results of this paper), it may still be the case that banks play a role in economic fluctuations, but more broadly as part of the "financial accelerator" or "broad credit channel" mechanism proposed by Bernanke and Gertler(1989) and Bernanke, Gertler and Gilchrist(1996) and tested by Oliner and Rude$\operatorname{busch}(1996)$.

The second finding adds to the negative results found at the aggregate level by Miron, Romer and Weil 1994), Oliner and Rudebusch(1996) and others that the lending channel has little or ambiguous macroeconomic impact. Further research is needed to pin down to what degree varying capacity utilization, changes in inventories or changes in the form of finance can buffer firms from banking shocks.

Finally, the current approach could also be applied to regions in other 
countries, or other collections of small open economies under fixed exchange rates, such as the European Union. 


\section{References}

Barnett, W. A., D. Fisher and A. Serletis, 1992. "Consumer Theory and the Demand for Money." Journal of Economic Literature, 2086-2119.

Berger, A. N. and T. H. Hannan,1989. "The Price-Concentration Relationship in Banking." Review of Economics and Statistics, 291-299.

A. K. Kashyap and J. M. Scalise, 1995. "The Transformation of the U.S. Banking Industry: What a Long, Strange Trip it's Been." Brookings Papers on Economic Activity, Vol. 2, 55-218.

Bernanke, B. S., 1983. "Nonmonetary Effects of the Financial Crisis in the Propagation of the Great Depression." American Economic Review, $73(2), 257-276$.

and A. Blinder, 1988. "Credit, Money and Aggregate Demand." American Economic Review, Papers and Proceedings,75(1),435-439.

and M. Gertler, 1989. "Agency Costs, Net Worth, and Business Fluctuations." American Economic Review,76(1),14-31.

- and S. Gilchrist, 1996. "The Financial Accelerator and the Flight to Quality." Review of Economics and Statistics,78(1),1-15.

and C. S. Lown, 1991. "The Credit Crunch." Brookings Papers on Economic Activity,205-247.

Blanchard, O. and L. Katz, 1992. "Regional Evolutions." Brookings Papers on Economic Activity,1-61.

Bodenhorn, H., 1995. "A More Perfect Union: Regional Interest Rates in the United States, 1880-1960." In Bordo, M.D. and R. Sylla, eds. Anglo-American Financial Systems. Irwin Publishing, New York NY, 415-455.

Brunner, K. and A. H. Meltzer, 1963. "The Place of Financial Intermediaries in the Transmission of Monetary Policy." American Economic Review, 372-382. 
Buch, C. M. ,2000. "Financial Market Integration in the U.S.: Lessons for Europe?" Manuscript, Kiel Institute of World Economics.

Bureau of Economic Analysis, 1989. 'State Personal Income: 1929-198\%.

Cyrnak, A.W. and T.H. Hannan, 1999. "Is the Cluster Still Valid in Defining Banking Markets? Evidence from a New Data Source." The Antitrust Bulletin, 313-331.

Davis, L. E., 1995. "Discussion: Financial Integration Within and Between Counties." In Bordo, M. D. and R. Sylla, eds. Anglo-American Financial Systems. Irwin Publishing, New York NY, 415-455.

Driscoll, J. C. and A. C. Kraay, 1998. "Consistent Covariance Matrix Estimation with Spatially Dependent Panel Data." Review of Economics and Statistics, LXXX(IV),549-560.

Eichengreen, B., 1984. "Mortgage Interest Rates in the Populist Era." American Economic Review, 995-1015.

Eichenbaum, M., 1994. "Comment." In N. G. Mankiw, ed. Monetary Policy University of Chicago Press, Chicago IL, 256-261.

Federal Deposit Insurance Corporation, 1934-1978. Assets and Liabilities of Commercial and Mutual Savings Banks.

— 1979-1983. Bank Operating Statistics.

- 1998. Historical Statistics on Banking: A Statistical History of the U.S. Banking Industry.

Federal Home Loan Bank Board, 1948-1967. Combined Financial Statements for FSLIC-Insured SELS.

—_, 1968-1984. Federal Home Loan Bank Board Journal.

Fuerst, T., 1992. "Liquidity, Loanable Funds and Real Activity." Journal of Monetary Economics, 29(1),3-24. 
Gertler, M. and S. Gilchrist, 1993. "The Role of Credit Market Imperfections in the Monetary Transmission Mechanism: Argument and Review." Scandinavian Journal of Economics, 95(1), 1993, 43-64. and - 1994. "Monetary Policy, Business Cycles and the Behavior of Small Manufacturing Firms." Quarterly Journal of Economics, 109(2), 309-340.

Hall, B. J, 1993. "Bank Lending and Income Growth: Evidence From Panel Data". Manuscript, Harvard University.

Holtz-Eakin, D., W. Newey and H. S. Rosen, 1988. "Estimating Vector Autoregressions with Panel Data". Econometrica, 56(6),1371-1395.

Kashyap, A.K. and J. Stein, 1994. "Monetary Policy and Bank Lending." In N. G. Mankiw, ed. Monetary Policy. University of Chicago Press, Chicago IL, 221-256.

- and - 2000. "What Do a Million Observations on Banks Say about the Transmission of Monetary Policy." American Economic Review, 407-428.

- - and D. W. Wilcox, 1983. "Monetary Policy and Credit Conditions: Evidence from the Composition of External Finance." American Economic Review, 83(1),78-98.

Miron, J., C. D. Romer and D. Weil, 1994. "Historical Perspectives on the Monetary Transmission Mechanism." In Mankiw, N. G., ed., Monetary Policy, University of Chicago Press, Chicago IL.

Morgan, D. P., 1992. "Bank Loan Commitments and the Lending View of Monetary Policy". Manuscript.

Mulligan, C. and Xavier Sala-i-Martin, 1992. "U.S. Money Demand:

Surprising Cross-Sectional Estimates." Brookings Papers on Economic Activity, 285-329

Oliner, S. D. and G. D. Rudebusch, 1996. "Is There a Broad Credit Channel for Monetary Policy?". Federal Reserve Bank of San Francisco Economic Review, 300-309. 
Ostergaard, C., 2000. "External Financing Constraints and Bank Loan Supply: Does the Structure of the Banking Sector Matter?" Manuscript, Norwegian School of Management.

Peek, J. and E.S. Rosengren, 1995a. "Bank Regulation and the Credit Crunch." Journal of Banking and Finance, 679-92. and — 1995b. "The Capital Crunch: Neither a Borrower Nor a Lender Be" Journal of Money, Credit and Banking, 625-638.

— and — 2000. "Collateral Damage: Effects of the Japanese Bank Crisis on Real Activity in the United States." American Economic Review, 30-45.

$\longrightarrow$ - and G. M. B. Tootell, 2000. "Identifying the Macroeconomic Effect of Loan Supply Shocks." Manuscript, Federal Reserve Bank of Boston.

Romer, C.D. and D. Romer, 1990. "New Evidence on the Monetary Tranmission Mechanism." Brookings Papers on Economic Activity.

Rotemberg, J.J., 1984. "A Monetary Equilibrium Model With Transactions Costs. Journal of Political Economy, 92(1),40-58.

— J. C. Driscoll and J.M. Poterba, 1995. "Money, Output and Prices: Evidence from a New Monetary Aggregate." Journal of Business 8 Economic Statistics, 67-83.

Samolyk, K. A., 1994. "Banking Conditions and Regional Economic Performance: Evidence of a Regional Credit Channel." Journal of Monetary Economics. 34(3), 259-278.

Savage, D. T., 1987. "Interstate Banking Developments." Federal Reserve Bulletin, 73(2),79-92.

Staiger, D. A. and J. H. Stock, 1997. "Instrumental Variables Regressions with Weak Instruments." Econometrica, 65(3), 557-586.

Wang, H., 2001. "Production Smoothing When Bank Loan Supply Shifts: The Role of Variable Capacity Utilization." Journal of Money, Credit and Banking, 33(3),749-766. 
Table 1

OLS Regressions of Output on Loans

Dependent Variable: $\Delta \tilde{y}_{i t}$

\begin{tabular}{|c|c|c|c|c|c|c|c|c|c|c|}
\hline & \multicolumn{6}{|c|}{ 1965-1998 } & \multicolumn{4}{|c|}{$\begin{array}{l}1976-1998 \\
\end{array}$} \\
\hline & \multicolumn{2}{|c|}{ C\&I Loans } & \multicolumn{2}{|c|}{$\begin{array}{c}\text { Total Loans } \\
\text { Including S\&Ls }\end{array}$} & \multicolumn{2}{|c|}{ Total Loans } & \multicolumn{2}{|c|}{ C\&I Loans } & \multicolumn{2}{|c|}{ Total Loans } \\
\hline & State & Region & State & Region & State & Region & State & Region & State & Region \\
\hline$\Delta \tilde{y}_{i t-1}$ & .120 & $.276^{* *}$ & .120 & $.278^{* *}$ & .126 & $.284^{* *}$ & .094 & $.397^{* *}$ & .098 & $.405^{* *}$ \\
\hline & (.105) & $(.108)$ & $(.106)$ & $(.110)$ & $(.106)$ & $(.110)$ & $(.105)$ & $(.105)$ & $(.106)$ & (.109) \\
\hline$\Delta \tilde{y}_{i t-2}$ & -.009 & .143 & -.009 & $.149^{*}$ & -.008 & .144 & .057 & .054 & .060 & .054 \\
\hline & $(.081)$ & $(.074)$ & $(.082)$ & $(.074)$ & $(.005)$ & $(.076)$ & $(.100)$ & $(.114)$ & $(.100)$ & $(.118)$ \\
\hline$\Delta \tilde{l}_{i t}$ & $.017^{* *}$ & $.012^{* *}$ & $.015^{* *}$ & $.009^{* *}$ & $.012^{*}$ & .007 & $.006^{* *}$ & $.014^{* *}$ & $.006^{* *}$ & $.007^{* *}$ \\
\hline & $(.006)$ & $(.004)$ & $(.005)$ & $(.003)$ & $(.005)^{* *}$ & $(.002)$ & $(.002)$ & $(.003)$ & $(.001)$ & $(.002)$ \\
\hline$\Delta \tilde{l}_{i t-1}$ & $.009 *$ & $.006^{*}$ & $.007^{*}$ & .003 & .005 & .003 & $.008^{* *}$ & .003 & $.004^{*}$ & .002 \\
\hline & $(.004)$ & $(.003)$ & $(.003)$ & $(.003)$ & $(.003)$ & $(.002)$ & $(.003)$ & $(.003)$ & $(.002)$ & $(.001)$ \\
\hline$\Delta \tilde{l}_{i t-2}$ & .007 & .001 & $.006^{*}$ & .001 & .005 & .002 & .003 & .000 & .003 & .002 \\
\hline & $(.004)$ & $(.003)$ & $(.003)$ & $(.002)$ & $(.003)$ & $(.001)$ & $(.003)$ & $(.003)$ & $(.002)$ & $(.001)$ \\
\hline$\overline{F_{3, \# O b s-5}}$ & $3.88^{* *}$ & $3.17^{*}$ & $3.44^{*}$ & 2.48 & 2.48 & $3.53^{*}$ & $6.03^{* *}$ & $6.74^{* *}$ & $8.72^{* *}$ & $4.13^{* *}$ \\
\hline \# Obs. & 1488 & 279 & 1488 & 279 & 1488 & 279 & 960 & 180 & 960 & 180 \\
\hline $\bar{R}^{2}$ & .037 & .158 & .036 & .152 & .029 & .147 & .034 & .229 & .030 & .207 \\
\hline
\end{tabular}

Note: $\tilde{x}_{i t}=x_{i t}-\sum_{i=1}^{N} x_{i t}$, i.e. $x_{i t}$ is demeaned from its cross-sectional average. 'State' indicates the cross-sectional unit consists of 48 states (50 states + DC less the three money-center states of New York, California and Illinois), and 'Region' indicates the unit is the nine census regions. The third-to-last row

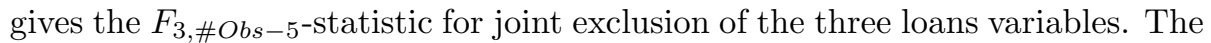
$1 \%$ and $5 \%$ critical values for an $F_{3, \infty}$ statistic are 3.78 and 2.60 , respectively. ${ }^{* *}$, and ' $*$ ' denote significance at the $1 \%$ and $5 \%$ level. 
Table 2

First Stage IV Regression: Loans on Money Demand Shock

Dependent Variable: $\Delta \tilde{l}_{i t}$

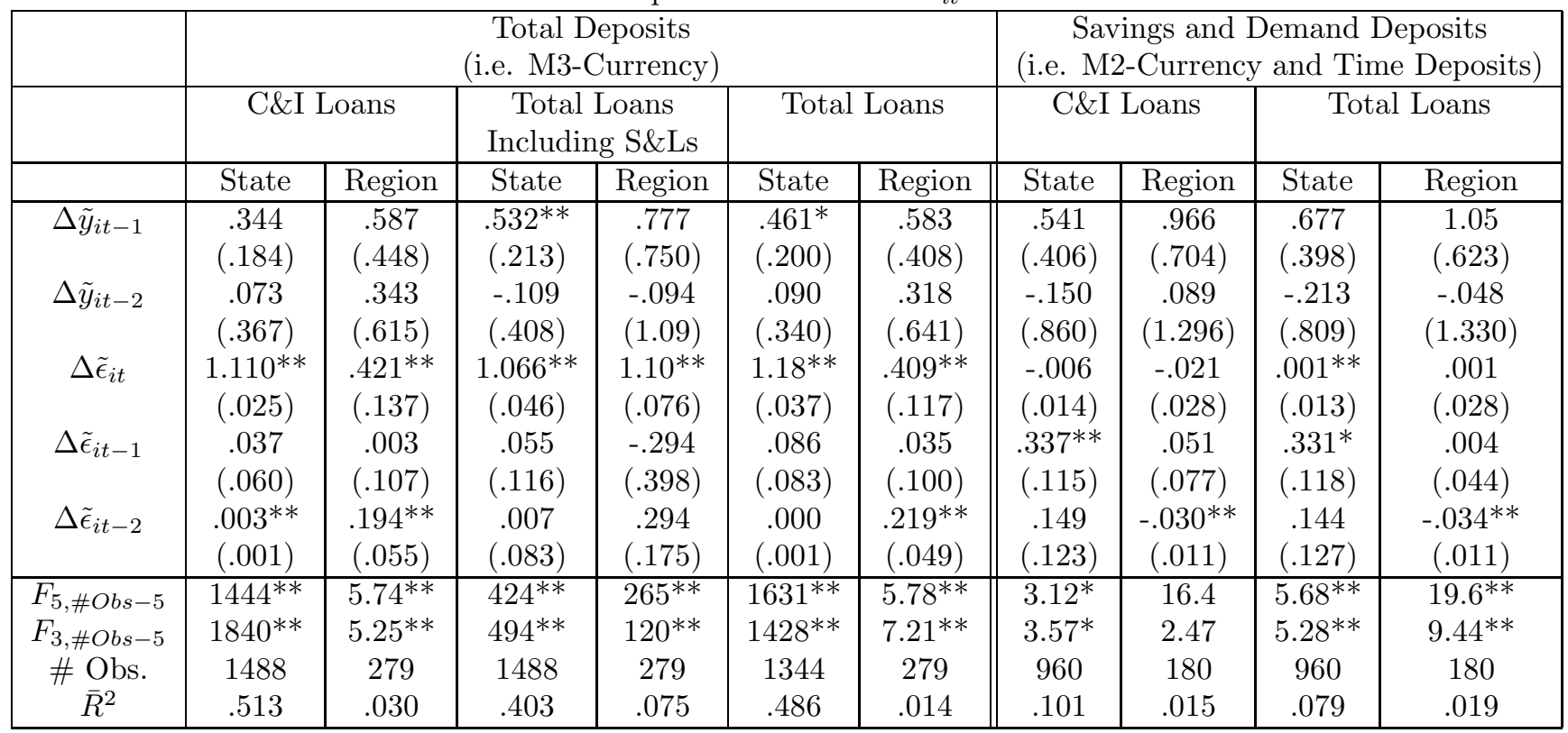

Note: $\epsilon_{i t}$ denotes a state-level money demand shock. All other notation as in previous table. 
Table 3

Second Stage of IV Regression: Output on Loans

Dependent Variable: $\Delta \tilde{y}_{i t}$

\begin{tabular}{|c|c|c|c|c|c|c|c|c|c|c|}
\hline & \multicolumn{6}{|c|}{$1965-1998$} & \multicolumn{4}{|c|}{$\begin{array}{l}1976-1998 \\
\end{array}$} \\
\hline & \multicolumn{2}{|c|}{ C\&I Loans } & \multicolumn{2}{|c|}{$\begin{array}{c}\text { Total Loans } \\
\text { Including S\&Ls }\end{array}$} & \multicolumn{2}{|c|}{ Total Loans } & \multicolumn{2}{|c|}{ C\&I Loans } & \multicolumn{2}{|c|}{ Total Loans } \\
\hline & State & Region & State & Region & State & Region & State & Region & State & Region \\
\hline$\Delta \tilde{y}_{i t-1}$ & $.093^{* *}$ & $.322^{*}$ & $.107^{* *}$ & $.278^{* *}$ & $.099^{* *}$ & .307 & .055 & .016 & .080 & -1.94 \\
\hline & $(.034)$ & (.161) & $(.027)$ & $(.078)$ & $(.033)$ & $(.161)$ & $(.261)$ & $(2.76)$ & $(.181)$ & (141) \\
\hline$\Delta \tilde{y}_{i t-2}$ & -.004 & .050 & .016 & .106 & -.033 & .055 & .068 & .049 & .067 & 3.24 \\
\hline & $(.006)$ & $(.140)$ & $(.027)$ & $(.073)$ & $(.062)$ & $(.152)$ & (.131) & (1.78) & $(.146)$ & $(172)$ \\
\hline$\Delta \tilde{l}_{i t}$ & -.002 & .024 & .000 & -.004 & -.001 & .018 & .006 & .112 & .006 & .157 \\
\hline & $(.004)$ & $(.046)$ & $(.004)$ & $(.016)$ & $(.003)$ & $(.049)$ & $(.008)$ & $(.584)$ & $(.009)$ & (15) \\
\hline$\Delta \tilde{l}_{i t-1}$ & .004 & -.052 & .014 & -.007 & .014 & -.043 & .054 & .156 & .023 & 1.28 \\
\hline & $(.013)$ & $(.100)$ & $(.008)$ & $(.020)$ & $(.011)$ & $(.112)$ & $(.261)$ & $(.998)$ & $(.151)$ & $(73)$ \\
\hline$\Delta \tilde{l}_{i t-2}$ & .068 & .068 & .000 & .029 & .061 & .071 & -.022 & -.176 & -.010 & -1.45 \\
\hline & $(.071)$ & $(.075)$ & $(.007)$ & $(.019)$ & $(.066)$ & $(.092)$ & $(.151)$ & $(.722)$ & (.128) & $(78)$ \\
\hline$\overline{F_{3, \# O b s-5}}$ & 1.03 & .310 & 1.39 & .804 & .995 & .237 & .188 & .025 & .223 & .001 \\
\hline \# Obs. & 1488 & 279 & 1488 & 279 & 1488 & 279 & 960 & 180 & 960 & 180 \\
\hline
\end{tabular}

Note: Notation as in the previous tables. Money demand shocks used as instruments; measure of money is total deposits (i.e. M3) less currency. 
Table 4

Robustness Checks

\begin{tabular}{|c|c|c|c|c|c|c|c|c|c|c|c|}
\hline \multicolumn{4}{|c|}{ OLS Regressions } & \multicolumn{4}{|c|}{ IV Regressions: First Stage } & \multicolumn{4}{|c|}{ IV Regressions: Second Stage } \\
\hline \multicolumn{4}{|c|}{ Dependent Variable: $\Delta \tilde{y}_{i t}$} & \multicolumn{4}{|c|}{ Dependent Variable: $\Delta l_{i t}$} & \multicolumn{4}{|c|}{ Dependent Variable: $\Delta \tilde{y}_{i t}$} \\
\hline & $\begin{array}{c}1938- \\
1998\end{array}$ & $\begin{array}{l}\text { Small } \\
\text { States }\end{array}$ & $\begin{array}{c}\text { No Fed } \\
\text { Banks }\end{array}$ & & $\begin{array}{c}1938- \\
1998\end{array}$ & $\begin{array}{l}\text { Small } \\
\text { States }\end{array}$ & $\begin{array}{c}\text { No Fed } \\
\text { Banks }\end{array}$ & & $\begin{array}{c}1938- \\
1998\end{array}$ & $\begin{array}{l}\text { Small } \\
\text { States }\end{array}$ & $\begin{array}{c}\text { No Fed } \\
\text { Banks }\end{array}$ \\
\hline$\Delta \tilde{y}_{i t-1}$ & $\begin{array}{l}-.185 \\
(.098)\end{array}$ & $\begin{array}{c}.095 \\
(.123)\end{array}$ & $\begin{array}{c}.101 \\
(.105)\end{array}$ & $\Delta \tilde{y}_{i t-1}$ & $\begin{array}{l}.041^{* *} \\
(.014)\end{array}$ & $\begin{array}{c}.223 \\
(.177)\end{array}$ & $\begin{array}{l}.344^{*} \\
(.171)\end{array}$ & $\overline{\Delta \tilde{y}_{i t-1}}$ & $\begin{array}{c}.159^{* *} \\
(.025)\end{array}$ & $\begin{array}{c}.088 \\
(.048)\end{array}$ & $\begin{array}{l}.085^{*} \\
(.037)\end{array}$ \\
\hline$\Delta \tilde{y}_{i t-2}$ & $\begin{array}{c}-.089 * * \\
(.020)\end{array}$ & $\begin{array}{l}-.013 \\
(.074)\end{array}$ & $\begin{array}{c}.012 \\
(.087)\end{array}$ & $\Delta \tilde{y}_{i t-2}$ & $\begin{array}{c}.044 \\
(.029)\end{array}$ & $\begin{array}{c}.144 \\
(.284)\end{array}$ & $\begin{array}{c}.035 \\
(.351)\end{array}$ & $\Delta \tilde{y}_{i t-2}$ & $\begin{array}{c}-.062^{* *} \\
(.017)\end{array}$ & $\begin{array}{l}-.040 \\
(.085)\end{array}$ & $\begin{array}{l}-.043 \\
(.065)\end{array}$ \\
\hline$\Delta \tilde{l}_{i t}$ & $\begin{array}{l}.397^{* *} \\
(.011)\end{array}$ & $\begin{array}{l}.010^{* *} \\
(.002)\end{array}$ & $\begin{array}{l}.008^{* *} \\
(.002)\end{array}$ & $\Delta \tilde{\epsilon}_{i t}$ & $\begin{array}{l}.237^{* *} \\
(.062)\end{array}$ & $\begin{array}{c}1.01^{* *} \\
(.032)\end{array}$ & $\begin{array}{c}1.16^{* *} \\
(.024)\end{array}$ & $\Delta \tilde{l}_{i t}$ & $\begin{array}{r}-.566^{* *} \\
(.067)\end{array}$ & $\begin{array}{l}-.001 \\
(.008)\end{array}$ & $\begin{array}{l}-.002 \\
(.005)\end{array}$ \\
\hline$\Delta \tilde{l}_{i t-1}$ & $\begin{array}{l}.157^{* *} \\
(013)\end{array}$ & $\begin{array}{r}.004 \\
(004)\end{array}$ & $.008^{* *}$ & $\Delta \tilde{\epsilon}_{i t-1}$ & $.146^{* *}$ & .079 & .037 & $\Delta \tilde{l}_{i t-1}$ & $.175^{* *}$ & .013 & .002 \\
\hline$\Delta \tilde{l}_{i t-2}$ & $\begin{array}{l}.071^{* *} \\
(.012)\end{array}$ & $\begin{array}{c}.006 \\
(.005)\end{array}$ & $\begin{array}{l}.004^{*} \\
(.004)\end{array}$ & $\Delta \tilde{\epsilon}_{i t-2}$ & $\begin{array}{l}.075^{*} \\
(.034)\end{array}$ & $\begin{array}{l}.013^{* *} \\
(.003)\end{array}$ & $\begin{array}{l}.002^{*} \\
(.001)\end{array}$ & $\Delta \tilde{l}_{i t-2}$ & $\begin{array}{c}.089 \\
(.106)\end{array}$ & $\begin{array}{c}.038 \\
(.095)\end{array}$ & $\begin{array}{c}.074 \\
(.078)\end{array}$ \\
\hline $\begin{array}{c}F_{5, \# O b s-5} \\
F_{3, \# O b s-3} \\
\text { \# Obs. }\end{array}$ & $\begin{array}{c}468^{* *} \\
2340\end{array}$ & $\begin{array}{c}6.33^{* *} \\
527\end{array}$ & $\begin{array}{c}6.71^{* *} \\
1209\end{array}$ & & $\begin{array}{c}6.55^{* *} \\
5.80^{* *} \\
2340\end{array}$ & $\begin{array}{c}78.5^{* *} \\
566^{* *} \\
527\end{array}$ & $\begin{array}{c}239^{* *} \\
1444^{* *} \\
1209\end{array}$ & & $\begin{array}{l}71^{* *} \\
2340\end{array}$ & $\begin{array}{l}.315 \\
527\end{array}$ & $\begin{array}{l}.745 \\
1209\end{array}$ \\
\hline
\end{tabular}

Note: Notation as in the previous tables. C\&I Loans used. Money measure is total deposits. 


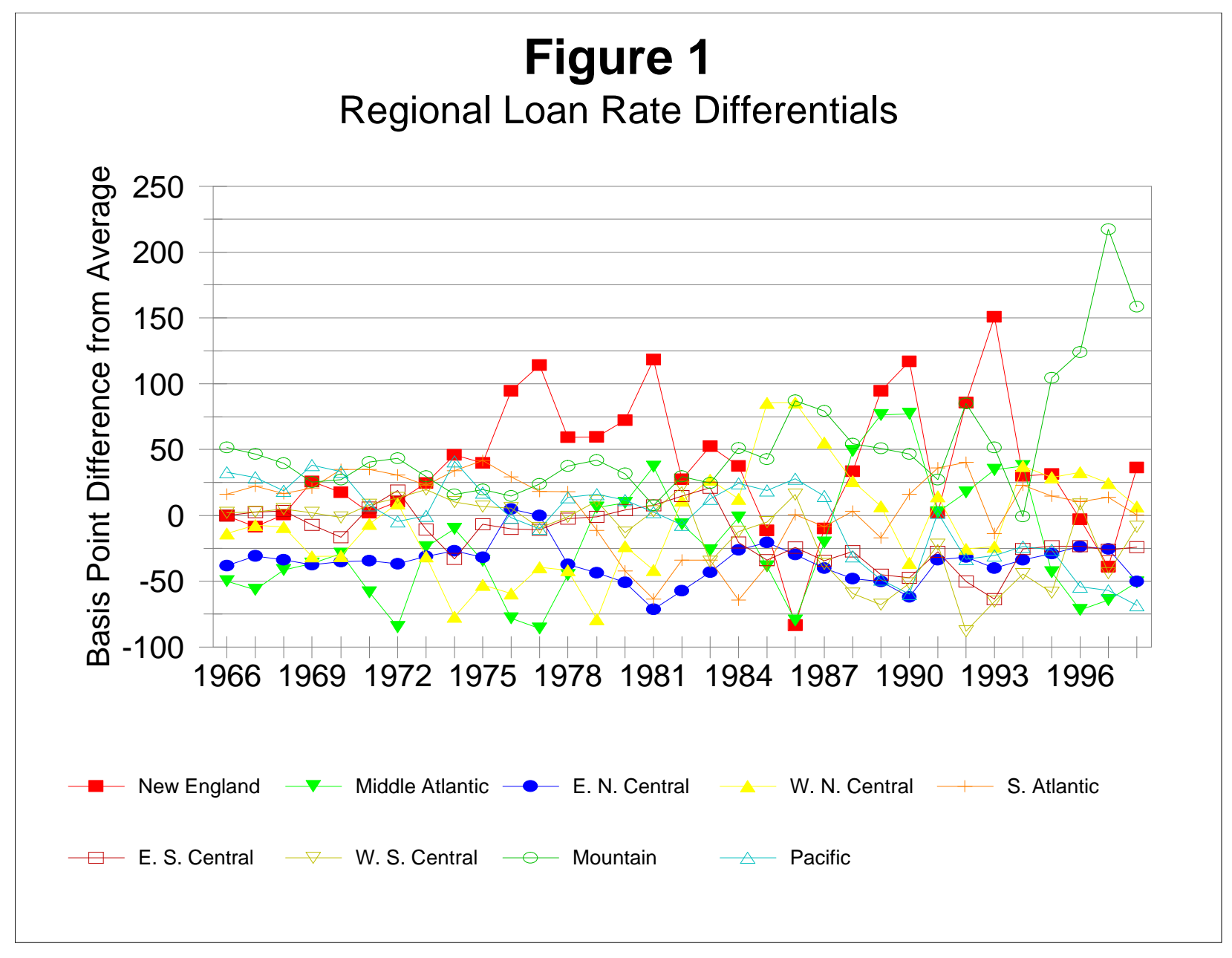

